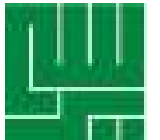

\title{
Diabetes Mellitus Tipe 2 sebagai Faktor Predisposisi dan Komorbid Tuberkulosis Multi Drug Resisten Primer
}

\section{Diabetes Mellitus Type 2 as Predisposing and Comorbid Factors of Primary Multi Drug Resistance Tuberculosis}

\author{
Ulfahimayati, Irvan Medison, Dessy Mizar:? \\ Departemen Pulmonologi dan Kedokteran Respirasi Fakultas \\ Kedokteran Universitas Andalas/RSUP DR. M. Djamil \\ Padang, Indonesia
}

KATA KUNCI KEYWORDS

ABSTRAK

ABSTRACT Multi Drug Resistant Tuberculosis (MDR-TB) was a health problem in worldwide. Indonesia was one of the 27 countries
with a high burden of MDR TB in the world, an estimated 6800 problem in worldwide. Indonesia was one of the 27 countries
with a high burden of MDR TB in the world, an estimated 6800

TB MDR Primer, DM Tipe 2, Skrining

Primary MDR-TB, Type-2 DM, Screening

Multi Drug Resistant Tuberculosis (MDR-TB) merupakan masalah kesehatan di Dunia saat ini. Indonesia termasuk 27 negara dengan high burden MDR TB di dunia, diperkirakan 6800 kasus baru per tahun, 2,8\% merupakan kasus baru dan $16 \%$ pernah mendapatkan obat anti tuberculosis (OAT) sebelumnya. MDR TB primer terjadi pada pasien yang sebelumnya tidak pernah mendapat pengobatan OAT. Diabetes mellitus merupakan faktor predisposisi dan komorbid yang dapat mempercepat terjadinya penyakit TB dan mempersulit pengobatannya. Tujuan laporan kasus ini untuk melaporkan kasus MDR TB primer pada pasien dengan DM type 2. Kasus pasien laki-laki 58 tahuh dengan gejala batuk produktif dengan sputum kekuningan sejak 2 bulan, keringat malam dan penurunan berat badan. Hasil tes cepat molekuler menunjukkan MTB detected medium dan rifampicin resistant detected. Rontgen toraks infiltrate dan cavitas di apex paru. Pasien denga DM type-2 tidak terkontrol selama 12 tahun dengan HbA1c 10,5\%. Kami menyimpulkan bahwa DM merupakan salah satu konkommitant faktor predisposisi dan komorbid MDR TB primer. Pada pasien dengan DM perlu dilakukan skrining $T B$ dan sebaliknya pasien TB juga perlu dilakukan skrining DM. Terapi MDR TB dengan DM sesuai dengan paduan standar nasional terapi MDR TB dan menjaga kadar gula darah tetap terkontrol. 
new cases per year, $2.8 \%$ were new cases and $16 \%$ have received anti TB drugs before. Primary MDR TB occured in patient who have never received anti TB drugs treatment. Diabetes mellitus was a predisposing and comorbid factor that could accelerate TB disease and complicate treatment. We reported primary MDR TB case in patient with type 2 diabetes. Case of male 58 years old with a history of productive cough with yellowish phlegm since 2 months, night sweats and loss of weight and appetite. Rapid molecular test resulted MTB detected medium and rifampicin resistant detected. Chest $X$-ray showed infiltrate and cavity at the apex of the lung. Patients with type 2 diabetes mellitus have not been controlled for 12 years with $\mathrm{HbA1c}$ $10.5 \%$. We concluded that DM is one of predisposing and comorbid factors of primary MDR TB. DM patients were necessary to do TB screening and TB patients also need to be screened for DM. MDR TB treatment in DM patient complied with the national standard MDR TB treatment and blood sugar levels remain under control.

\section{PENDAHULUAN}

Multi Drug Resistant Tuberculosis (MDR-TB) adalah resistensi kuman Mycobacterium Tuberculosis (MTB) terhadap isoniazid (INH) dan rifampisin dengan atau tanpa OAT lini pertama lain, misalnya resisten $\mathrm{HR}$, HRE, HRES. Kasus Tuberculosis (TB) baru di dunia secara umum 10 juta kasus, dan diperkirakan 400 juta kasus diabetes mellitus tahun 2017, dan 558.000 kasus adalah MDR TB dengan resisten rifampisin dan INH. TB dan Diabetes mellitus (DM) termasuk 10 besar penyebab kematian karena infeksi di dunia setelah infeksi HIV (WHO, 2019 dan Ali S et al., 2019).

Song dkk tahun 2019 di China melaporkan TB DM pada TB kasus baru di India 54\%, Kepulauan Pasifik 40\% dan Meksiko 25\%. Studi epidemiologi dan analisis sekuensing DNA MTB didapatkan kebanyakan adalah MDR TB karena infeksi primer dan DM adalah salah satu konkommitant faktor risiko MDR TB. Penelitian di India, Spanyol dan Turki didapatkan 10-23\% pasien MDR TB adalah dengan DM (Song et al., 2019).

Indonesia termasuk 27 negara dengan high burden MDR TB di dunia, diperkirakan 6800 kasus baru per tahun, 2,8\% merupakan kasus baru dan 16\% pernah mendapatkan OAT sebelumnya. Tahun 2016, terdapat 2293 pasien terkonfirmasi MDR TB dan 1420 (62\%) diantaranya merupakan kasus baru (WHO, 2019).

Resistensi primer pada MDR TB terjadi pada pasien yang sebelumnya tidak pernah mendapat pengobatan OAT atau telah mendapatkan OAT kurang dari 1 bulan.

\footnotetext{
Correspondence:

Ulfahimayati, Departemen Pulmonologi dan Kedokteran Respirasi Fakultas Kedokteran Universitas Andalas/RSUP DR. M. Djamil Padang, Indonesia

Email:uhimayati@gmail.com
} 
Kontak penularan dari droplet yang mengandung MTB yang telah mengalami resistensi obat akan menciptakan kasus baru pasien TB yang resistensi primer, pada akhirnya mengarah pada kasus MDR (PDPI, 2011).

Faktor risiko untuk berkembangnya TB menjadi MDR TB adalah koinfeksi HIV, malnutrisi, asap rokok dan DM tipe 2. DM tipe 2 adalah gangguan metabolik kronik yang disebabkan oleh kerusakan fungsi dari sel beta pankreas yang menyebabkan terjadinya resistensi insulin yang progresif dan inflamasi kronik (SeguraCerda et al., 2019). Penelitian yang dilakukan oleh Wan-mei dkk di China pada tahun 2004-2007 menemukan bahwa kasus MDR TB primer lebih tinggi pada pasien dengan DM dibandingkan dengan non-DM (Wanmei et al., 2017).

Perubahan metabolik pada pasien DM tipe 2 akan mempengaruhi infeksi TB dan progresivitas TB. Perubahan metabolik itu antara lain hiperglikemia, peningkatan $\mathrm{HbA1C}$, peningkatan trigliserida, penurunan HDL, penigkatan lipoprotein dan gangguan hormon lainnya (SeguraCerda et al., 2019).

\section{KASUS}

Laki-laki 58 tahun dengan keluhan utama batuk berdahak warna kekuningan sejak \pm 2 bulan sebelum masuk rumah sakit, memiliki riwayat batuk darah 1 minggu sebelum masuk rumah sakit, sesak napas kadangkadang, demam sub febril sejak 1 bulan, keringat malam dan penurunan berat badan $\pm 10 \mathrm{~kg}$ dalam 3 bulan terakhir. Pasien belum pernah menderita sakit TB dan minum obat anti TB. Pasien diketahui memiliki riwayat penyakit
DM sejak 12 tahun yang lalu dengan konsumsi metformin dan glimepirid. Tidak ada kontak dengan pasien TB atau MDR TB. Terdapat riwayat DM di keluarga (ibu). Pasien memiliki riwayat merokok dengan indeks brinkman berat. Pemeriksaan fisik menunjukkan pasien tampak sakit sedang, tanda vital dalam batas normal, BM1 $22 \mathrm{~kg} / \mathrm{m}^{2}$, didapatkan ronki pada kedua lapangan paru terutama di apeks paru. Pemeriksaan jantun dan abdomen tidak ada kelainan. Terdapt clubbing finger.

Dari hasil pemeriksaan rontgen toraks didapatkan gambaran infiltrat di apeks kedua lapangan paru disertai dengan cavitas di paru kiri (gambar 1). Hasil laboratorium didapatkan $\mathrm{Hb}$ 11,4g/dl, leukosit 6500/ul, trombosit $156.0000 / \mathrm{ul}$, hematokrit 36\%, GDS $320 \mathrm{mg} / \mathrm{dl}$, GDP $231 \mathrm{mg} / \mathrm{dl}$, GD2PP $207 \mathrm{mg} / \mathrm{dl}, \mathrm{HbA1c} 10,5 \%$ dan rapid test HIV non reaktif. Hasil pemeriksaan Xpert MTB/RIF didapatkan MTB detected low, rifampicin resistant detected.

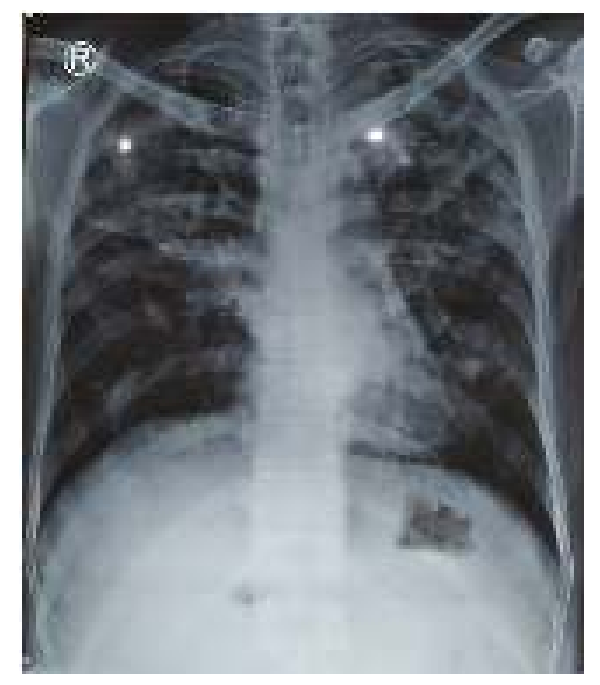

Gambar 1. Rontgen toraks

Pasien didiagnosis MDR TB dengan DM tipe 2 telah dikenal normoweight tidak terkontrol. Sesuai dengan algoritma pengobatan MDR TB, maka pasien ini dikelola sebagai MDR 
TB sambil menunggu hasil dari kultur MTB dan uji sensitivitas obat. Pasien direncanakan untuk diberikan OAT MDR dengan panduan jangka pendek yaitu kanamisinn, moxifloxacin, INH dosis tinggi, clofazimin, etionamid, etambutol dan pirazinamid. Sebelum mendapatkan terapi MDR, pasien dicek labor lengkap dan dikonsultasikan ke bagian Mata, THT, jantung dan kedokteran jiwa sebagai baseline untuk pemberian pengobatan OAT MDR. Hasil labor lengkap diantaranya; total protein $6,1 \mathrm{~g} / \mathrm{dl}$, albumin $3,0 \mathrm{~g} / \mathrm{dl}$, globulin 3,1g/dl, Bilirubin total 0,6, bilirubin direk $0,3 \mathrm{~g} / \mathrm{dl}$, bilirubin indirek 0,3g/dl, SGOT $22 \mathrm{U} / 1$, SGPT $19 \mathrm{U} / 1$, Ureum 11mg/dl, kreatinin 0,6mg/dl, kolesterol total $2222 \mathrm{mg} / \mathrm{dl}$, HDL $49 \mathrm{mg} / \mathrm{dl}$, LDL 117mg/dl, T3 <04ml/ dl, T4 4,58ml/dl, TSH 0,3ml/dl. Hasil konsul dari THT, mata, jiwa dan jantung tidak ada kelainan.

Insulin 3x6 IU perhari secara subkutan diberikan sebagai terapi DM type 2 dari dokter spesialis penyakit dalam. Paduan OAT MDR jangka pendek diberikan sesuai berat badan pasien $(60 \mathrm{~kg})$ diantaranya injeksi kanamisin 1x750mg, moxifloksasin 1x800mg, clofazimin 1x1000mg, etambutol 1x1000mg, pirazinamid 1x2000mg, INH $1 \times 600 \mathrm{mg}$, etionamid 1x750mg dan B6 1x100mg. Pasien juga dikonsulkan ke dokter gizi untuk pengaturan diet DM.

Hasil kultur MTB positif dan hasil uji kepekaan obat, resisten terhadap rifampisin dan INH serta sensitif terhadap streptomicin, etambutol, kanamisin, ofloxacin dan amikasin. Berdasarkan hasil tersebut terapi OAT MDR paduan jangka pendek pada pasien dilanjutkan. Untuk mengendalikan kadar gula darah, pasien diberikan pengaturan diet DM, olah raga ringan, injeksi insulin kerja singkat dengan dosis titrasi. Pasien juga diberikan vitamin B6 dosis tinggi 100 mg untuk mencegah kejadian neuropati.

\section{DISKUSI}

Berkembangnya kasus TB yang menjadi MDR pada umumnya terjadi karena manajemen yang tidak tepat dari penyediaan obat-obat anti TB, pengobatan TB yang tidak tepat, dan mudahnya transmisi penyakit di masyarakat yang padat penduduk. (WHO, 2016) Resistensi primer terjadi pada pasien yang sebelumnya tidak pernah mendapat pengobatan OAT atau telah mendapatkan OAT kurang dari 1 bulan. (WHO, 2019) Penularan berasal dari droplet yang mengandung kuman MTB yang telah resisten terhadap obat yang akan menciptakan kasus baru pasien TB yang resistensi primer, pada akhirnya mengarah pada kasus MDR TB. Data awal survei resistensi obat lini pertama yang dilakukan di Jawa Tengah pada tahun 2006, menunjukkan angka TB MDR pada kasus baru yaitu 2,07\%, angka ini meningkat pada pasien yang pernah diobati sebelumnya yaitu 16,3\% (Program Pengendalian TB Nasional Indonesia, 2008).

Pada kasus ini pasien di kategorikan sebagai pasien TB MDR primer karena pasien belum pernah mendapatkan OAT sebelumnya dan tidak pernah kontak dengan penderita TB MDR. Untuk menegakkan diagnosis TB MDR primer pada kasus ini telah dilakukan pemeriksaan Xpert MTB/RIF dengan hasil MTB detected medium dan rifampisin resistant detected. Resistensi natural adalah resistensi yang ditemukan pada strain liar yang timbul sebagai hasil multiplikasi berkelanjutan kuman-kuman tersebut. Populasi ini tidak signifikan. Resistensi pada strain 
liar tersebut harus terpapar suatu obat anti tuberkulosis agar terekspresi secara fenotip. Bila resistensi terjadi karena terapi yang tidak adekuat (monoterapi) maka resistensi yang terjadi bersifat didapat atau acquired resistance atau juga disebut resistensi sekunder. Jika pasien TB dengan resistensi sekunder ini menularkan pada orang lain yang belum mendapat OAT, maka resistensi yang terjadi adalah resistensi inisial atau resistensi primer (Soedarsono, 2010). Pada kasus ini mekanisme resistensi obat TB terjadi karena faktor kuman. Mutasi genetik yang menimbulkan obat tidak efektif melawan kuman yang mengalami mutasi. Basil tuberkulosis mempunyai kemampuan secara spontan melakukan mutasi kromosom yang mengakibatkan basil tersebut resisten terhadap obat antimikroba. Mutasi yang terjadi adalah unlinked,

oleh karenanya resistensi obat yang terjadi biasanya tidak berkenaan dengan obat yang tidak berhubungan. Munculnya resistensi obat menggambarkan peninggalan dari mutasi sebelumya, bukan perubahan yang disebabkan karena terpapar dengan pengobatan (Baghaei $\mathrm{P}$ et al., 2015).

Faktor risiko utama yang juga menyebabkan terjadinya MDR TB pada pasien ini adalah penyakit DM yang tidak terkontrol (Soelistijo SA, 2019). Perubahan metabolik pada pasien DM tipe-2 akan mempengaruhi infeksi TB dan progresivitas TB. Perubahan metabolik itu antara lain hiperglikemia, peningkatan $\mathrm{HbA1C}$, peningkatan trigliserida, penurunan HDL, penigkatan lipoprotein dan gangguan hormon lainnya. Tatalaksana imun untuk sindrom metabolik akan dikembangkan sebagai strategi baru untuk diagnosis, tatalaksana dan pencegahan tuberculosis (gambar 2) (Segura-Cerda et al., 2019).

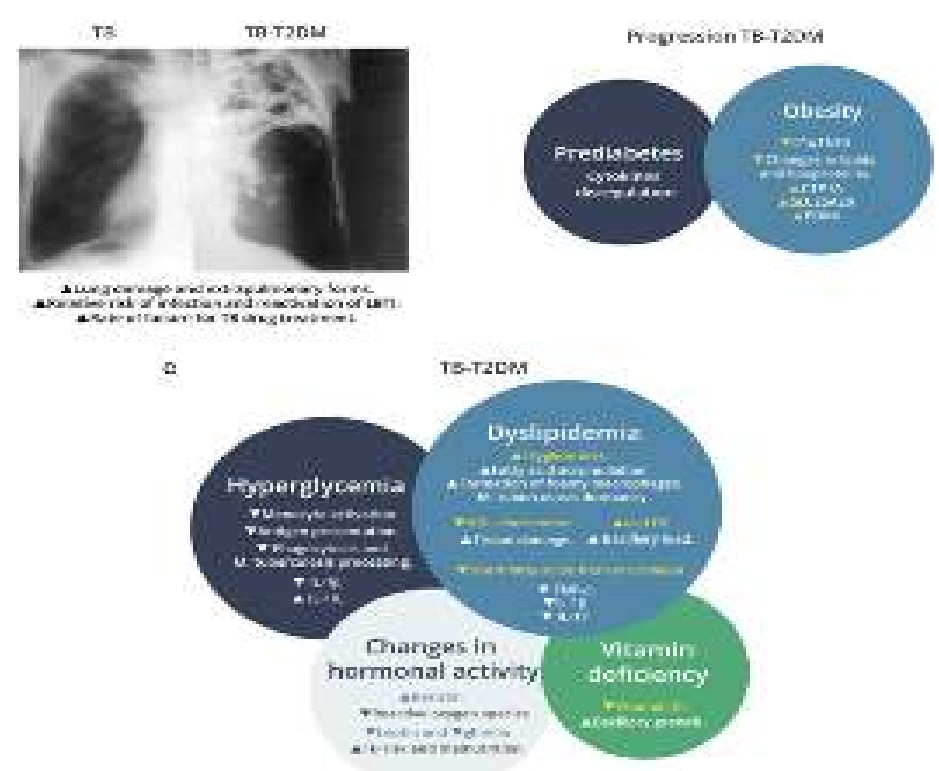

Gambar 2. Perubahan respon imun pada sindrom metabolic (Segura-Ceda et al., 2019).

Keadaan hiperglikemia kronis
pada DM dapat menyebabkan gangguan metabolisme glukosa sehingga merangsang pembentukan reactive oxygen species (ROS) yang dapat menggangu kerja dan motilitas makrofag alveolar dalam aktivitas imun melawan kuman MTB. Aktivasi system imun terhadap MTB terganggu pada kondisi DM, terjadi gangguan produksi IL12 yang diperlukan untuk mensensitasi sel T menjadi Th1 (CD4+) 
yang melepas IFNg dan TNFa. Sehingga penyakit TB yang terjadi pada psien DM lebi berat dan agresif serta memiliki kerusakan paru yang lebih parah dan sering terjadi resistensi terhadap obat TB. DM yang tidak terkontrol juga dapat menyebabkan ketoasidosis yang menurunkan efek bakterisidal dalam tubuh (Amare H et al., 2013).

DM dapat mempersulit diagnosis dan manajemen TB karena perubahan gambaran klinis dari penyakit TB dan perlambatan periode konversi sputum, selain itu DM juga mempengaruhi hasil pengobatan karena dapat memperlambat reaksi mikrobiologis terhadap obat, mempercepat perkembangan infeksi serta meningkatkan risiko kematian, risiko TB relaps dan MDR TB. Obat-obat untuk DM dan TB dapat berintegrasi sehingga menghambat aktivitas satu sama lainnya (Soelistijo SA, 2019). Rekomendasi untuk pasien DM dengan TB adalah: Pada pasien dengan DM perlu dilakukan skrining $\mathrm{TB}$ dan sebaliknya pasien TB juga perlu dilakukan skrining DM; Skrining dilakukan bila ada gejala klinis TB batuk lebih 2 minggu, skrining berupa pemeriksaan sputum dan rontgen toraks; Tatalaksana TB dengan DM tidak ada perbedaan dengan TB tanpa DM, kecuali jika DM tidak terkontrol waktu pengobatan dapat dilanjutkan sampai 9 bulan; Jika pasien mendapatkan obat jenis rifampisin maka gula harus dikontrol ketat karena rifampisin mengurangi efektifitas obat oral antidiabetik golongan sulfenilarea, dan dianjurkan untuk menggunakan obat antidiabetik seperti insulin yang dapat meregulasi gula darah tanpa mempengaruhi efektivitas obat.

Tatalaksana DM pada pasien ini adalah insulin 3×6 IU dari hasil konsul penyakit dalam. Pemberian insulin diharapkan tidak mempengaruhi efektivitas dari OAT. Gula darah pada pasien ini tetap tidak terkontrol dengan pemberian insulin karena pasien tidak mematuhi diet yang diberikan dari rumah sakit, pasien lebih suka membeli makanan dari luar. Semakin tidak terkontrol gula darah maka perkembangan infeksi akan meningkat dan konversi sputum akan semakin lama. Pasien ini harus diberikan konsultasi gizi yang baik untuk pengaturan diet selain pemberian obatobat antidiabetik.

Pasien ini diberikan terapi OAT MDR dengan paduan standar jangka pendek yaitu kanamisin, moxifloxacin, INH dosis tinggi, clofazimin, etionamid, etambutol dan pirazinamid. Syarat pemberian OAT MDR jangka pendek adalah pasien tidak terbukti resistensi florokuinolon, tidak ada kontak dengan pasien PreXDR atau XDR, tidak mendapat OAT lini 2>1 bulan, tidak ada intoleran terhadap OAT paduan jangka pendek, tidak hamil, bukan tb ekstra paru berat, bukan tb ekstra paru pada ODHA, dan bukan pasien dengan unpavorable outcome. Kriteria unpavorable outcome yaitu TB paru lesi luas dengan severe underweight, gizi buruk (BMI <16), Gangguan fungsi hati: kenaikan kadar SGOT/SGPT >5x normal, Gangguan fungsi ginjal: kreatinin klirens $<30 \mathrm{cc} /$ menit (gambar 3) (KEMENKES RI,2017).

Sebelum memulai pengobatan harus dilakukan persiapan awal termasuk pemeriksaan penunjang seperti: Anamnesis ulang untuk memastikan kemungkinan terdapat riwayat dan kecendrungan alergi obat tertentu, riwayat pennyakit dahulu seperti hepatitis, diabetes mellitus, gangguan ginjal dan kejiwaan, kejang, kesemutan sebagai gejala kelainan saraf tepi(neuropati perifer); Pemeriksaan : penimbangan berat badan, fungsi penglihatan, fungsi pendengaran, 
pemeriksaan kondisi kejiwaan berguna untuk menetapkan strategi konseling dan harus dilaksanakan sebelum, selama dan setelah pengobatan selesai, memastikan data dasar pasien terisi dengan benar dan terekam dalam sistem pencatatan yang digunakan (eTB manager dan pencatatan manual), kunjungan rumah dilakukan oleh petugas fasyankes wilayah untuk memastikan alamat yang jelas dan kesiapan keluarga untuk mendukung pengobatan melalui kerjasama jejaring eksternal, pemeriksaan baseline penunjang seperti: pemeriksaan darah lengkap, pemeriksaan kimia darah; faal ginjal (ureum, kreatinin), faal hati (SGOT, SGPT) serum elektrolit (natrium, kalium, klorida), asam urat, gula darah (puasa dan 2 jam puasa), pemeriksaan tiroid stimulating hormone, tes kehamilan untuk wanita usia subur, fototorak, tes pendengaran (audiometri), pemeriksaan EKG dan tes HIV (KEMENKES, 2016). Pemeriksaan ini dilakukan karena OAT MDR mempunyai efek samping ke telinga, mata, irama jantung, segmen QT memanjang dan gangguan jiwa seperti halusinasi

Pada pasien ini semua hasil labor dalam batas normal selain dari GDP dan GD2PP yaitu 231 dan 207. Hasil konsul dari THT, mata, jiwa dan jantung tidak ada kelainan. Pasien di rencanakan pemberian OAT MDR paduan jangka pendek, dan hasil LPA tidak ditemukan resistensi OAT lini 2. Paduan yang diberikan pada pasien ini adalah Injeksi kanamisin 1x750mg, Moxifloksasin 1x800mg, Clofazimin 1x1000mg, Etambutol 1x1000mg, Pirazinamid 1x2000mg, INH 1x600mg, Etionamid $1 \times 750 \mathrm{mg}$ dan B6 1x100mg, sesuai dengan berat badan pasien $60 \mathrm{~kg}$.

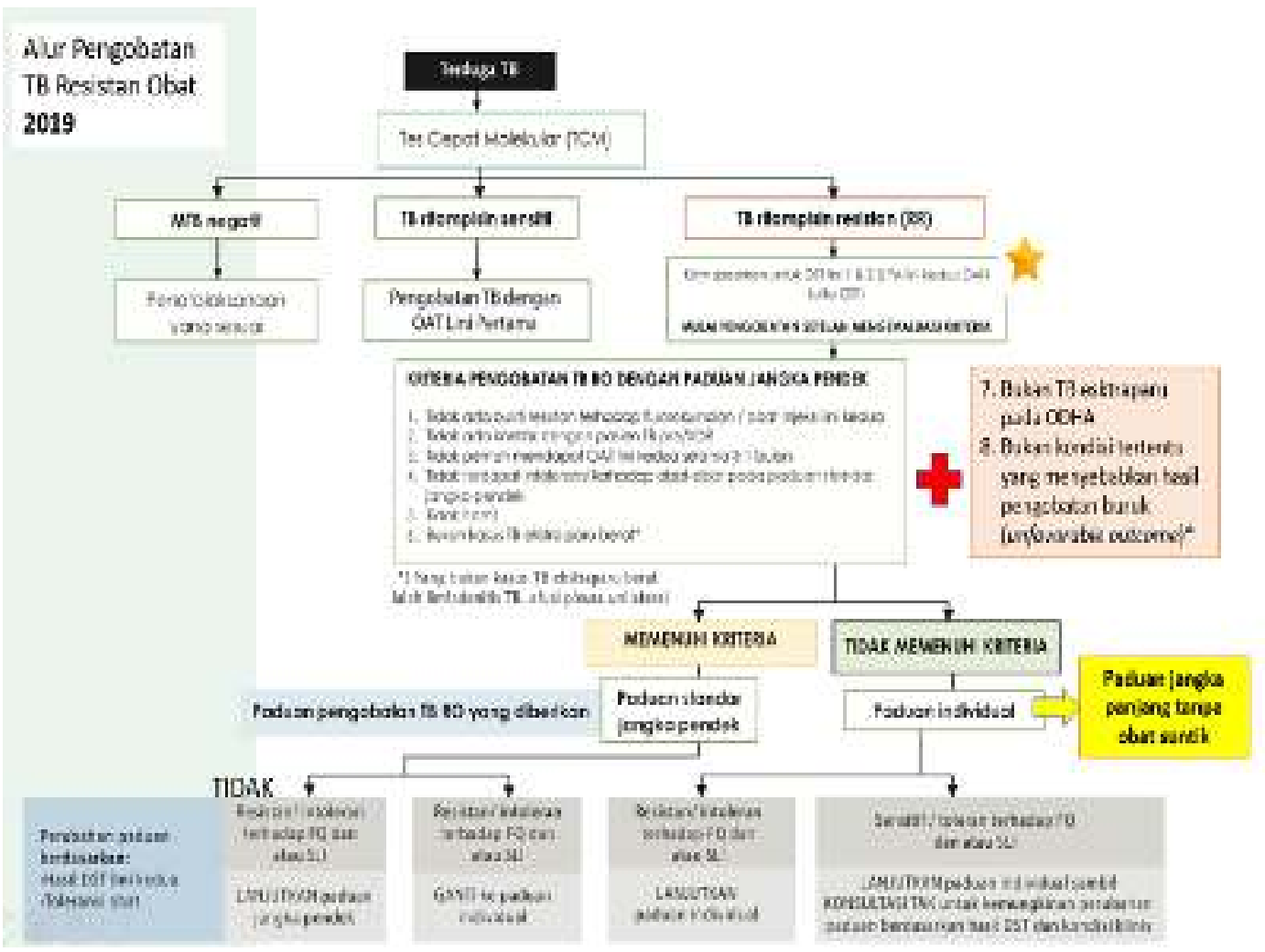

Gambar 3. Alur pengobatan TB resiten obat tahun 2019 (KEMENKES RI, 2017) 
Pengobatan pada pasien MDR TB mengikuti panduan yang ditetapkan secara nasional yaitu: Jangka pendek (shorter regimen selama 9-11 bulan): 4-6 Km-MfxEto(Pto)-HDT-Cfz-E-Z/5Mfx-Cfz-E-Z;

Diberikan dalam 2 tahap: tahap awal dan selama 4-6 bulan, tahap lanjutan diberikan selama 5 bulan (tabel 1 dan 2); Panduan OAT individual, ini diperuntukkan bagi pasien TB XDR dan TB preXDR serta untuk pasien yang memerlukan OAT jenis baru karena efek samping berat atau alergi.
Follow up pasien MDR TB yaitu dilakukan kultur dan pmeriksaan BTA tiap bulan selama fase intensif dan tiap 2 bulan selama fase lanjutan, pemeriksaan labor faal hepar, ginjal tiap bulan, elektrolit tiap bulan pada fase intensif, rontgen torak dilakukan pada bulan 1, ke 4, ke 6, dan ke 9. Pemeriksaan kadar gula darah pada pasien ini harus dilakukan setiap bulan untuk mengetahui apakah kadar gula darah terkontrol atau tidak sebagai follow up pengobatan DMnya (tabel 3) (KEMENKES RI, 2017).

\begin{tabular}{lc}
$\begin{array}{l}\text { Tabel 1. Obat pada paduan standar jangka pendek } \\
\text { Tahap awal }\end{array}$ & $\begin{array}{c}\text { Tahap lanjutan } \\
\text { (diberikan setiap }\end{array}$ \\
$\begin{array}{l}\text { (diberikan } \\
\text { hari selama 4-6 } \\
\text { bulan) }\end{array}$ & $\begin{array}{c}\text { setiap hari } \\
\text { selama 5 bulan) }\end{array}$ \\
\hline Kanamisin $(\mathrm{Km})$ & $\begin{array}{c}\text { Mfloxacin } \\
\text { Clofazimin }(\mathrm{Cfz})\end{array}$ \\
Moxifloxacin $(\mathrm{Mfx})$ & Etambutol $(\mathrm{E})$ \\
$\begin{array}{l}\text { Etionamid(Eto)/ } \\
\text { Protionamid(Pto) }\end{array}$ & \\
$\begin{array}{l}\text { Isoniazid dosis } \\
\text { tinggi (HDT) }\end{array}$ & Pirazinamid (Z) \\
Clofazimin (Cfz) & \\
Etambutol (E) & \\
Pirazinamid (Z) & \\
*Dikutip dari (KEMENKES RI, 2017)
\end{tabular}

Tabel 2. Dosis OAT paduan jangka pendek

\begin{tabular}{lcccc}
\cline { 1 - 3 } Nama Obat & \multicolumn{3}{c}{ Dosis berdasarkan kelompok berat } & \\
& $<33 \mathrm{~kg}$ & $33-50 \mathrm{~kg}$ & $>50-70 \mathrm{~kg}$ & $>70 \mathrm{~kg}$ \\
\hline Kanamisin & $0,5 \mathrm{~g}$ & $0,75 \mathrm{~g}$ & $0,75 \mathrm{~g}$ & $1 \mathrm{~g}$ \\
Moxifloxacin & $400 \mathrm{mg}$ & $600 \mathrm{mg}$ & $800 \mathrm{mg}$ & $800 \mathrm{mg}$ \\
Clofazimin & $50 \mathrm{mg}$ & $100 \mathrm{mg}$ & $100 \mathrm{mg}$ & $100 \mathrm{mg}$ \\
Etambutol & $600 \mathrm{mg}$ & $800 \mathrm{mg}$ & $1000 \mathrm{mg}$ & $1200 \mathrm{mg}$ \\
Pirazinamid & $750 \mathrm{mg}$ & $1500 \mathrm{mg}$ & $2000 \mathrm{mg}$ & $2000 \mathrm{mg}$ \\
Isoniazid DT & $300 \mathrm{mg}$ & $600 \mathrm{mg}$ & $600 \mathrm{mg}$ & $900 \mathrm{mg}$ \\
Etionamid & $500 \mathrm{mg}$ & $500 \mathrm{mg}$ & $750 \mathrm{mg}$ & $1000 \mathrm{mg}$ \\
Protionamid & $500 \mathrm{mg}$ & $500 \mathrm{mg}$ & $750 \mathrm{mg}$ & $1000 \mathrm{mg}$ \\
\cline { 1 - 3 } & &
\end{tabular}

*Dikutip dari (KEMENKES RI, 2017) 


\section{Tabel 3. Follow up pasien MDR}

\begin{tabular}{|c|c|c|c|c|c|c|c|c|c|c|c|}
\hline \multirow{4}{*}{$\begin{array}{c}\text { Jenis } \\
\text { pemeriksaan }\end{array}$} & \multicolumn{11}{|c|}{ Bulan pengobatan } \\
\hline & \multicolumn{6}{|c|}{$\begin{array}{l}\text { Tahap awal } 4 \text { bulan (dapat } \\
\text { diperpanjang sampai } 6 \text { bulan }\end{array}$} & \multicolumn{5}{|c|}{ Tahap lanjutan 5 bulan } \\
\hline & 0 & 1 & 2 & 3 & 4 & & & 56 & 7 & 8 & 9 \\
\hline & 0 & 1 & 2 & 3 & 4 & 5 & 6 & $\begin{array}{ll}7 & 8\end{array}$ & 9 & 10 & 11 \\
\hline Anamnesis & $\overline{\mathrm{V}}$ & $\overline{\mathrm{V}}$ & $\overline{\mathrm{V}}$ & $\overline{\mathrm{V}}$ & $\mathrm{V}$ & $\overline{\mathrm{V}}$ & $\overline{\mathrm{V}}$ & $\begin{array}{ll}\mathrm{V} \\
\mathrm{V}\end{array}$ & $\mathrm{V}$ & $\mathrm{V}$ & $\mathrm{V}$ \\
\hline $\begin{array}{l}\text { Pemeriksaan } \\
\text { fisik/ klinis BB }\end{array}$ & $\mathrm{V}$ & V & $\mathrm{V}$ & V & $\mathrm{V}$ & $\mathrm{V}$ & $\mathrm{V}$ & $\mathrm{V} \quad \mathrm{V}$ & $\mathrm{V}$ & $\mathrm{V}$ & $\mathrm{V}$ \\
\hline BTA sputum & V & V & V & V & VV & $\mathrm{VV}$ & $\mathrm{VV}$ & $\mathrm{V}$ & $\mathrm{V}$ & & VV \\
\hline Biakan sputum & $\mathrm{V}$ & $\mathrm{V}$ & V & V & $\mathrm{V}$ & V & V & V & $\mathrm{V}$ & & $\mathrm{V}$ \\
\hline LPA lini kedua & $\mathrm{V}$ & & & & & & & & & & \\
\hline Uji kepekaan & $\mathrm{V}$ & & & & & & $\mathrm{VV}$ & & & & \\
\hline EKG & $\mathrm{V}$ & V & V & V & V & $\mathrm{V}$ & $\mathrm{V}$ & $\mathrm{V} \quad \mathrm{V}$ & $\mathrm{V}$ & $\mathrm{V}$ & V \\
\hline Tes pendengaran & $\mathrm{V}$ & & & & & & & & & & \\
\hline Tes penglihatan & $\mathrm{V}$ & & & & & & & & & & \\
\hline Rontgen torak & V & & & & $\mathrm{V}$ & & V & & & & V \\
\hline Darah lengkap & $\mathrm{V}$ & & & & & & & & & & \\
\hline GDp/GD2PP & $\mathrm{V}$ & & & & & & & & & & \\
\hline $\begin{array}{l}\text { Ureum kreatinin } \\
\text { serum }\end{array}$ & V & V & V & V & $\mathrm{V}$ & $\mathrm{V}$ & $\mathrm{V}$ & & & & \\
\hline Elektrolit & $\mathrm{V}$ & V & V & V & $\mathrm{V}$ & V & $\mathrm{V}$ & & & & \\
\hline SGOT/SGPT, & V & & & & & & & & & & \\
\hline bilirubin total & & & & & & & & & & & \\
\hline TSH/TSHs & V & & & & & & & & & & \\
\hline TEs kehamilan & V & & & & & & & & & & \\
\hline Tes HIV & $\mathrm{V}$ & & & & & & & & & & \\
\hline
\end{tabular}

*Dikutip dari (KEMENKES RI, 2017)

Hasil kultur MTB positif dan uji sensitivitas obat, sensitif terhadap streptomicin, etambutol, kanamisin, ofloxacin dan amikasin, serta resisten terhadap rifampisin dan INH. Berdasarkan hasil tersebut terapi OAT MDR paduan jangka pendek pada pasien dilanjutkan.

\section{KESIMPULAN}

Diabetes mellitus dapat mempercepat perkembangan infeksi serta peningkatan risiko TB relaps dan MDR TB. DM merupakan salah satu konkommitant faktor predisposisi dan komorbid MDR TB primer. Pada pasien dengan DM perlu dilakukan skrining TB dan sebaliknya pasien TB juga perlu dilakukan skrining DM. Terapi MDR TB dengan DM sesuai dengan paduan standar nasional terapi MDR TB dan menjaga kadar gula darah tetap terkontrol.

\section{KEPUSTAKAAN}

Ali S, Rose Alinda A, Syed Norris H, Marlia P, Siti Hamisah T, Cotet GB, et al., 2019. World Health Statistic 2019 [Internet]. Vol. 2, WHO. 2018. 5-7 p.

Amare H, Gelaw A, Anagaw B, Gelaw B 2013. Smear positive pulmonary tuberculosis among diabetic patients at the Dessie referral hospital, Northeast Ethiopia. Infect Dis Poverty. 2013;2(1):2-9.

Baghaei P, Tabarsi P, Moniri A, Marjani M, Velayati AA 2015. Impact of diabetes mellitus on tuberculosis drug resistance in new cases of 
tuberculosis. International Journal of Mycobacteriology. 2015; 4: 128.

Kementerian Kesehatan Republik Indonesia 2016. Petunjuk teknis pengobatan pasien TB resisten Obat dengan paduan standar jangka pendek di fasyankes TB resisten obat. 1st ed. Jakarta: Kemenkes; 2016. 1-40 p.

Kementerian Kesehatan Republik Indonesia 2017. Petunjuk Teknis Pengobatan Pasien TB Resistan Obat dengan Paduan Standar Jangka Pendek Di Fasyankes TB Resistan Obat. 1st ed. Jakarata: Kementrian Kesehatan RI; 2017. 2-30 p.

Perhimpunan Dokter Paru Indonesia 2011. Tuberculosis: pedoman diagnosis dan penatalaksanaan di Indonesia. PDPI. 2011. 1-64.

Program Pengendalian TB Nasional Indonesia 2008. Pedoman Diagnosa dan pengobatan programatik TBMDR (MDR) dan TBXDR (XDR) dalam konteks proyek uji pendahuluan Green Light Committee, Juni 2008.

Segura-Cerda CA, López-Romero W, Flores-Valdez MA 2019. Changes in Host Response to Mycobacterium tuberculosis Infection Associated With Type 2 Diabetes: Beyond Hyperglycemia. Front Cell Infect Microbiol. 2019;9(October):1-10.
Soedarsono 2010. Genesis of MDR TB: clinically and program aspect. Majalah Kedokteran Respirasi. Vol. 1.2010. 12-18.

Soelistijo SA 2019. Pedoman Pengelolaan dan Pencegahan Diabetes MEllitus Tipe 2 Dewasa di Indonesia tahun 2019. 1st ed. Soelistijo SA, editor. Jakarta: PB PERKENI; 2019. 68-9 p.

Song WM, Shao Y, Liu JY, Tao NN, Liu Y, Zhang QY, et al., 2019 Primary drug resistance among tuberculosis patients with diabetes mellitus: A retrospective study among 7223 cases in China. Infect Drug Resist. 2019;12:2397-407.

Wan-mei Song,Yang Shao, Jinyue Liu, Ning-ning Tao, Yao Liu, Qianyun Zhang, et al., 2017 Primary drug resistance among tuberculosis patients with diabetes mellitus: a retrospective study among 7223 cases in China. Infection and Drug Resisten. 2017.

World Health Organization 2016. WHO treatment guidelines for drugresistant tuberculosis 2016. 1st ed. Geneva: WHO; 2016.

World Health Organization 2019. Global Tuberrculosis Report 108. 1st ed. Geneva; 2019. 27-72 p. 